\title{
Poznavanje izabranih radnih prava među maturantima srednjih strukovnih škola u Hrvatskoj
}

DOI: $10.5613 /$ rzs.51.1.2

UDK 373.5:6]-057.87:349.2

316.644-057.87:349.2](497.5)

Izvorni znanstveni rad

Primljeno: 13. 10. 2020.

\author{
Ranka JEKNIĆ (D) https://orcid.org/0000-0001-8503-3634 \\ Pravni fakultet Sveučilišta u Splitu, Hrvatska \\ ranka.jeknic@pravst.hr \\ Blanka ČOP (D) https://orcid.org/0000-0002-2519-0993 \\ Pravni fakultet Sveučilišta u Splitu, Hrvatska \\ blanka.cop@pravst.hr
}

\section{SAŽETAK}

$U$ radu se analiziraju rezultati anketnog istraživanja o poznavanju izabranih radnih prava među maturantima srednjih strukovnih škola u Hrvatskoj. Istraživanje je provedeno tijekom 2019. u okviru EU projekta Znanjem do prava na uzorku od 1102 maturanta iz 54 srednje strukovne škole različitih trogodišnjih, četverogodišnjih i petogodišnjih programa. Primjenom deskriptivne statistike i regresijske analize, $u$ radu se nastoji ustanoviti postoje li razlike u pokazanom znanju o radnim pravima i povezanost sociodemografskih i obrazovanih karakteristika ispitanika s razinom pravne pismenosti. Rezultati upućuju na njihovo relativno slabo poznavanje i nisku razinu pravne pismenosti iz područja izabranih radnih prava te povezanost sociodemografskih i obrazovnih obilježja ispitanika s indeksom ukupnog znanja o izabranim radnim pravima. Regresijska analiza pokazuje kako varijabla spola ima najveći utjecaj na razinu pravne pismenosti među ispitanim maturantima srednjih strukovnih škola. Osim u sagledavanju aktualnog stanja u pogledu znanja ispitanih maturanata srednjih strukovnih škola o izabranim radnim pravima, te poticanju akademskih i javnih rasprava, nalazi ovog istraživanja mogu imati aplikativnu vrijednost pri izradama plana i programa građanskog odgoja i obrazovanja na različitim obrazovnim razinama, kao i za razvoj i planiranje sindikalnog djelovanja u Hrvatskoj u pogledu regrutacije novog članstva. Istraživački nalazi potencijalno pridonose i kod nas nedovoljno istraženim temama pravnog znanja, pravne pismenosti, pravne kulture i pravne socijalizacije putem koje se ta znanja usvajaju.

Ključne riječi: radna prava, pravna socijalizacija, pravna pismenost, strukovne škole, građanski odgoj i obrazovanje

Zahvaljujemo suradnicima i učenicima koji su sudjelovali u istraživanju, uredništvu časopisa Revija za sociologiju, a posebno članu uredništva Teu Matkoviću i svim recenzentima na komentarima i preporukama kojima su značajno pomogli unaprijediti tekst. 


\section{UVOD}

Problematika transformacije rada, radnih odnosa i zaposlenosti posljednjih nekoliko desetljeća zauzima važno mjesto u suvremenim sociološkim analizama postindustrijalizma, modernosti, globalizacije, razvoja informacijskih tehnologija itd. Neovisno o tome je li riječ o autorima koji proučavaju promjene suvremenog svijeta rada s naglaskom na razvoj "postindustrijskih društava" (Bell, 1973), "programiranih društava" (Touraine, 1971), "umreženih društava" (Castells, 2000), "društava rizika" (Beck, 2000), "tekuće modernosti" (Bauman, 2000), širenje "neoliberalne doxe" globalizacije (Bourdieu, 1999: 35), zajedničko im je isticanje i analiziranje fenomena i procesa transformacije i karaktera rada poput individualizacije rada $i$ radnih odnosa, nesigurnosti, privremenosti, nestalnosti, odnosno fleksibilizacije i prekarizacije rada.

Fleksibilizacija, liberalizacija i deregulacija tržišta rada dovode i do rasta nestandardnih oblika zaposlenosti i agencijskog rada, smanjivanja utjecaja sindikata i razine socijalnih prava. Pod utjecajem fleksibilnosti je i radno zakonodavstvo, što se u slučaju hrvatskoga najvažnijeg zakonodavnog okvira, konkretnije Zakona o radu, intenzivira izmjenama 2014. godine kad se novim Zakonom "indeks zakonske zaštite zaposlenja smanjio s 2,55 na 2,28” (Butković i dr., 2018: 13).

Efektima fleksibilnosti tržišta rada posebno su pogođene ranjive skupine, kao što su mladi u posttranzicijskim i postsocijalističkim društvima, kakvo je i hrvatsko društvo. Na to jasno upućuju dosad provedena istraživanja o položaju mladih u Hrvatskoj (llišin, 1999, 2006, 2007; Ilišin i Radin, 2002; llišin, Mendeš i Potočnik, 2003; Ilišin i Radin, 2007; llišin i dr., 2013; Ilišin i Spajić Vrkaš, 2017; Gvozdanović i dr., 2019). Mladi su heterogena društvena skupina unutar koje postoje unutargeneracijske razlike s obzirom na dob, obrazovni status, socioekonomski položaj, obiteljsko podrijetlo, razinu uključenosti na tržište rada i u društvo. Njihova uključenost u svijet odraslih i preuzimanje društvenih uloga najprije se događa ulaskom na tržište rada čime su, uslijed različitih procesa liberalizacije te rasta nesigurnih i slabo plaćenih poslova, posebno pogođeni mladi koji se nalaze na prijelazu iz obrazovnog u sustav zapošljavanja (Ilišin i dr., 2003; Gvozdanović i dr., 2019) i mladi koji završe srednje trogodišnje strukovne škole (Matković i dr., 2013). Plaćeni poslovi koji im se nude sve su nesigurniji (prekarniji) i češće je riječ o sezonskim poslovima (Matković i dr., 2013: 26). Prema Eurostatu (2019), na razini EU-a Hrvatska se $\mathrm{s} 43,5 \%$ zaposlenih mladih u dobi od 15 do 29 godina nalazi ispod prosjeka 27 članica EU-a koji iznosi $48,2 \%$, odnosno pri dnu ljestvice uz Rumunjsku $(42,4 \%)$ i Bugarsku $(42,1 \%)$, dok se na samom dnu nalaze Grčka $(31,3 \%)$ i Španjolska $(38,2 \%)$.Unutar skupine mladih od 15 do 34 godine najranjiviji su mladi koji se nalaze izvan obrazovnog sustava i tržišta rada (NEET) među kojima u po- 
sljednjih nekoliko godina u Hrvatskoj uočavamo trend opadanja (npr. tijekom 2016. godine u Hrvatskoj in je bilo 19,5\%, u 2017. oko 18\%, u 2018. 15,6\%, a u 2019. oko 14\%) (Eurostat, 2020). Unatoč smanjenju opsega najranjivije skupine mladih u RH posljednjih godina, navedeni podatci još uvijek Hrvatsku smještaju iznad prosjeka 27 članica EU-a koji iznosi 12,6\% za 2019., odnosno uz Španjolsku (14,9\%), Slovačku (14,5\%) i Cipar (14,1\%) (Eurostat, 2020). Osim toga, prema rezultatima recentnog "Istraživanja mladih u Hrvatskoj 2018./2019.", kad je riječ o sklapanju radnog odnosa, manji postotak mladih radi puno radno vrijeme (22\% na neodređeno i $18 \%$ na određeno puno radno vrijeme), a kad je riječ o prosječnom radnom vremenu mladih, $51 \%$ zaposlenih mladih radi više od 40 sati tjedno (Gvozdanović i dr., 2019: 25).

Prijelaz iz sustava obrazovanja na tržište rada posebno je izazovan u uvjetima visoke nezaposlenosti kad su mnogi mladi zbog nedostatka radnog iskustva $i$ nužnosti pronalaska posla prisiljeni pristajati na nesigurne i fleksibilne oblike rada i zaposlenosti. Uz stručna znanja koja su im potrebna za obavljanje nekog posla, poznavanje pravnih propisa iz radnog prava omogućava im prepoznavanje situacija i postupak poslodavca koje ih mogu dovesti u neravnopravan položaj i narušiti im prava i dostojanstvo. Stoga se ovaj rad fokusira na jedan dio populacije mladih na prijelazu iz obrazovnog sustava u svijet rada, odnosno na maturante srednjih strukovnih škola u Hrvatskoj koji se ulaskom na tržište rada mogu suočavati s (potencijalno) nepovoljnim uvjetima zapošljavanja i rada te povredom radnih prava. Cilj je istraživanja utvrditi razinu pravne pismenosti među maturantima srednjih strukovnih škola, odnosno njihovo poznavanje odabranih radnih prava i propisa kojima se uređuje položaj radnika u $\mathrm{RH}$.

Budući da pregledom literature nisu pronađena slična istraživanja o poznavanju pravnih propisa kojima se uređuje položaj radnika u Hrvatskoj, u nastavku ćemo istaknuti rezultate dvaju istraživanja provedenih na reprezentativnom uzorku među radno aktivnom populacijom u Velikoj Britaniji. Spomenuta istraživanja ispitivala su razinu osviještenosti radnika o njihovim pravima iz radnog odnosa, kao i njihovo znanje o radnim pravima mjereno s pomoću poznavanja odabranih pravnih propisa iz radnog prava (poput razine minimalne plaće, ograničenja radnog vremena, prava na plaćeni odmor, roditeljskog dopusta, diskriminacije na radnom mjestu itd.) (Caseborne i dr., 2006; Meager i dr., 2002). Rezultati spomenutih istraživanja pokazuju povezanost razine znanja o pravnim propisima iz radnog prava $s$ nekim sociodemografskim i profesionalnim karakteristima ispitanika. Tako nižu razinu znanja pokazuju grupe radnika koje su i najranjivije na tržištu rada (mlađi i stariji radnici, honorarni radnici i oni s nižim plaćama) (Caseborne i dr., 2006: 4), kao i pripadnici etničkih manjina, privremeno zaposleni i radnici s nižim kvalifikacijama (Meager i dr., 2002: 207). Veću razinu znanja o radnim pravima pokazuju skupine 
radnika s višim kvalifikacijama, stalno zaposleni na puno radno vrijeme, članovi sindikata te radnici na menadžerskim i u profesionalnim zanimanjima (Meager i dr., 2002: 207).

S obzirom na to da je riječ o nedovoljno istraženoj temi, iako postoje ograničenja nalaza jer je uzorak prigodan, autorice vide potencijal empirijskih uvida ovog istraživanja kojim se želi odgovoriti na sljedeća specifična pitanja:

1. Koliko ispitani maturanti srednjih strukovnih škola poznaju pravne propise kojima se uređuju izabrana individualna i kolektivna prava iz radnog odnosa?

2. Postoje li među ispitanim učenicima razlike u pokazanom znanju o pravnim propisima s obzirom na neke karakteristike ispitanika (spol, školski uspjeh, mjesto stanovanja, radno iskustvo)?

\section{PRAVNA SOCIJALIZACIJA, PRAVNA PISMENOST I PRAVNA KULTURA}

Pravna je socijalizacija poseban oblik socijalizacije tijekom koje se razvijaju "vrijednosti, stavovi i ponašanja prema pravilima i pravu" (Finckenauer, 1998: 31). Odnosi se na procese putem kojih članovi društva stječu svoje "pravne vrijednosti (pravednost, jednakost, pravda) te norme ponašanja" koje su u skladu s tim vrijednostima i s pravnom kulturom tog društva (Cohn i White, 1997: 152). To je "proces učenja o ponašanjima koja su propisana pravilima i zakonima" i učenja o normama, kao i o sankcijama koje se trebaju primjenjivati, a propisane su "ili od strane vladajuće strukture ili pravnom kulturom" (Cohn i White, 1990: 80). Među klasičnim teorijama pravne socijalizacije mogu se izdvojiti dvije teorije iz područja socijalne psihologije. Prva je teorija "razvoja pravnog rasuđivanja" koja stavlja naglasak na "unutarnje" faktore, a predstavlja primjenu Kohlbergove teorije tri razine razvoja u moralnom rasuđivanju (pretkonvencionalnu - engl. "sanction oriented" ili "rule obeying"; konvencionalnu - engl. "law and order" ili "rule maintaining"; i postkonvencionalnu - engl. "law creating" ili "rule making"). Druga je "teorija socijalnog učenja" koja stavlja naglasak na "vanjske" faktore, a predstavlja primjenu Bandurine teorije socijalnog učenja po kojoj moralno ponašanje proizlazi iz "učenja opažanjem" te ističe utjecaj socijalnog okruženja i pravne kulture na normativno ponašanje (Tapp i Kohlberg, 1971: 69; Tapp i Levine, 1974: 20; Cohn i White, 1990; Cohn i White, 1997). Riječ je o dvjema posve različitim teorijama pravne socijalizacije, no treba ih razumjeti kao međusobno nadopunjujuće, a ne isključujuće pristupe analiziranja učenja putem kojih se odvija pravna socijalizacija (Cohn i White, 1990). Pri analiziranju procesa i učinaka pravne socijalizacije, uz "unutarnje" i "vanjske" faktore, 
treba uzimati u obzir i vezu i interakciju između kognitivnih procesa i društvene okoline (Cohn i White, 1990).

Većina građana stječe osnovna znanja o državi, pravu, normama, zakonima, pravima i obvezama i razvija strategije za njihovo korištenje tijekom cjeloživotne socijalizacije. Kao najvažniji primarni agensi pravne socijalizacije ističu se "obitelj, škola(e), i religija”, jer su "u poziciji određivati pravni sadržaj”, iako ne treba zanemariti važnost i utjecaj ostalih agensa poput medija, društvenih mreža i grupe vršnjaka (Cohn i White, 1990: 14). Budući se pravna socijalizacija provodi "formalno i neformalno" (Finckenauer, 1998: 31) i tijekom različitih razdoblja života, kao agense pravne socijalizacije treba spomenuti i sudjelovanje u primjenama prava u različitim organizacijama (udrugama, klubovima i sl.), participacijom u lokalnoj zajednici (javne rasprave, radionice i sl.), u radnoj sredini (sindikatima, radničkim vijećima) itd.

lako pravna socijalizacija i učenje različitih pravnih znanja traju cijeli život, za usvajanje znanja relevantnih za pravno zaključivanje i razvoj pravnog mišljenja važno je razdoblje djetinjstva i adolescencije kad se općenito usvajaju vrijednosti, razvijaju procesi zaključivanja i obrasci ponašanja (Tapp i Kohlberg, 1971; Tapp i Levine, 1974). Sve ono naučeno tijekom tih godina trajno utječe i na daljnji razvoj tijekom kasnijeg života i zrelosti, tako i pravna socijalizacija i usvajanje pravnih znanja tijekom tih godina imaju cjeloživotne posljedice za pojedince (s izuzetkom onih koji prolaze formalno pravno obrazovanje tijekom studija) (Tapp i Kohlberg, 1971; Tapp i Levine, 1974). Pritom nije riječ samo o širenju pravne pismenosti, kao učenju i usvajanju osnovnih znanja o "pravima, resursima i pravnim lijekovima", zakonima, normama, pozitivno pravnim propisima i mehanizmima zaštite različitih prava, nego poticanju postkonvencionalnog razumijevanja prava te osposobljavanju i pravnom opismenjavanju djece i mladih kao budućih "konzumenata", ali i budućih "kreatora" prava (Tapp i Levine, 1974: 32). Tek je na postkonvencionalnoj razini pravnog razvoja lakše razumjeti sadržaj i važnost temeljnih ljudskih prava, radnih i socijalnih prava kao ljudskih prava, kulturnih i drugih prava i "važnost rješavanja socijalnih, ekonomskih i političkih problema u najboljem interesu za sve članove društva" (Tapp i Levine, 1974: 42). Kao sastavni dio pravne socijalizacije, u školama kao temeljnim obrazovnim i odgojnim institucijama za provedbu pravne socijalizacije mladih, i njihovog obrazovanja o pravu ${ }^{1}$, potrebno je širiti pravno znanje i pravnu pismenost mladih jer bez posjedovanja "nekih informacija o zakonima osoba ne može djelovati učinkovito i koristiti usluge ili osigurati sebi svoja prava" (Tapp i Levine, 1974: 32). Ili kako je to sažeto formulirano u staroj latinskoj poslovici - "ignorantia iuris nocet” (nepoznavanje prava škodi).

U radu se koristi sintagma "obrazovanje o pravu" kako bi se razlikovalo općenito obrazovanje djece i mladih o pravu, od formalnoga "pravnog obrazovanja" koje se stječe tijekom studija prava (Finckenauer, 1998: 33). 
Pravna socijalizacija je i proces putem kojeg članovi društva uče ili usvajaju pravnu kulturu kao sastavni dio kulture svoga društva. Pritom je određenje pravne socijalizacije kao procesa putem kojeg pojedinci razvijaju "vrijednosti, stavove i ponašanja prema pravu", kao i razvoj individualnih standarda za donošenje pravnih zaključaka, "rješavanje konflikata, podizanje tužbi i rješavanje sporova" (Tapp i Levine, 1974: 4) u skladu s Friedmanovom (1969: 34) definicijom pravne kulture kao "mreže vrijednosti i stavova prema pravu, a koji pak određuju kada će, zašto i gdje ljudi okrenuti prema pravu i vladi ili će se okrenuti od njih". Treba naglasiti da je pojam pravne kulture složen i višedimenzionalan te se sastoji od "pravnog znanja" (prisutnog među širokim slojevima stanovništva), "specijaliziranog (stručnog) znanja” (pravnika i službenih osoba), "poznavanja alternativnih i supsidijarnih normi” (koje koegzistiraju uz oficijelni pravni poredak), vrijednosti kao koncepcije poželjnoga te "pravnog osjećaja ili pravnog ethosa" (Vrban, 2006: 200-201). Takva konceptualizacija pojma pravne kulture u skladu je s Friedmanovim razlikovanjem vanjske i unutarnje pravne kulture, pri čemu se pod vanjskom misli na "pravnu kulturu običnoga puka", a pod unutarnjom na "pravnu kulturu onih članova društva koji obavljaju specijalizirane pravne zadatke" (Friedman, 1975, u: Kregar i dr., 2014: 208). Navedena određenja pravne socijalizacije, pravnog znanja, pravne pismenosti i pravne kulture, omogućila su teorijsko-konceptualni okvir za različita empirijska istraživanja o tome koliko djeca i mladi znaju o pravu općenito, koliko znaju o različitim pravima, kako razvijaju vrijednosti prema pravu i pravno rasuđivanje (Tapp i Kohlberg, 1971; Tapp i Levine, 1974; Cohn i White, 1990; Cohn i White, 1997; Finckenauer, 1998).

Dosadašnja istraživanja koja su mjerila poznavanje različitih prava i pravnih propisa pokazala su na nisku razinu poznavanja prava među djecom i mladima u Velikoj Britaniji (Ruck i dr., 1998; Youth Access, 2002; Denvir, Balmer i Buck, 2012), dok se neka druga istraživanja više usmjeravaju na istraživanje razine znanja o pravu i različitim implikacijama razine znanja o pravima među ukupnom populacijom (Meager i dr., 2002; Caseborne i dr., 2006; Buck, Pleasence i Balmer, 2008; Denvir i dr., 2012; Denvir, Balmer i Pleasence, 2013). Istraživački nalazi spomenutih istraživanja u Velikoj Britaniji upućuju na nisku razinu znanja o pravu među mladima i ukupnom populacijom i smatraju se empirijskom potvrdom nužnosti provedbe različitih incijativa okupljenih pod nazivom PLE (engl. Public Legal Education). PLE ili javno pravno obrazovanje omogućava "ljudima svijest, znanje i razumijevanje prava i pravnih pitanja, zajedno sa samopouzdanjem i vještinama koje su ljudima potrebni kako bi mogli ulaziti u sporove i ostvarivati pristup pravdi" (PLEAS Task Force, 2007: 9). Na tom tragu je Velika Britanija od 2002. godine uvela građansko obrazovanje u školski kurikul za djecu i mlade u dobi od 11 do 16 godina, uključujući na taj način informiranje o zakonima, pravima, procesima do- 
nošenja zakona, ljudskim pravima, kaznenom i građanskom pravu, zapošljavanju i radnim pravima i obvezama te pravima i odgovornostima potrošača u školsku nastavu (PLEAS Task Force, 2007: 18). U tom smislu, i u ovom radu, poznavanje pravnih propisa kojima se uređuju izabrana individualna i kolektivna radna prava u Hrvatskoj definirano je kao sastavni dio pravnog znanja mladih o radničkim pravima, pri čemu se to znanje smatra dijelom vanjske, pravne kulture mladih u Hrvatskoj. Pravna pismenost mladih određena je kao proizvod procesa usvajanja određenih znanja o radnim pravima, mehanizmima njihove zaštite i kolektivnim ugovorima. Pravna socijalizacija definirana je kao proces putem kojeg se usvajaju znanja o radnim pravima i propisima, razvija pravna pismenost i usvaja pravna kultura. Ipak, posjedovanje određenih pravnih znanja samo je jedan od više ciljeva i proizvoda pravne socijalizacije i jedan od elemenata pravne kulure, ali je važan i neophodan, iako nipošto i jedini uvjet za razvijanje i poticanje "integrativne, prilagodljive i kritičke misli" (Tapp i Levine, 1974: 32). Naposljetku, usvajanje pravnih znanja i pravna pismenost nužni su i za razvoj građanskih kompetencija koje uključuju "građansko znanje i razumijevanje, građanske vještine i sposobnosti te građanske vrijednosti i stavove" (Kovačić i Horvat, 2016: 15), a omogućuju aktivno sudjelovanje u različitim sferama društva te bolje razumijevanje "društvenih, gospodarskih, pravnih i političkih koncepata i struktura kao i globalnih promjena i održivosti" (GONG, 2018: 4).

\section{METODOLOGIJA}

Prikazani podatci prikupljeni su anketnim istraživanjem koje je provedeno tijekom travnja i svibnja 2019. godine u okviru projekta "Znanjem do prava", čiji je nositelj Sindikat zaposlenika u hrvatskom školstvu Preporod.

\subsection{Upitnik}

Anketni upitnik ${ }^{2}$ sastojao se od 42 pitanja podijeljena u 3 cjeline. Prva cjelina sadržava prvih deset pitanja i odnosi se na sociodemografske karakteristike ispitanika dok su u drugom dijelu pitanja koja se odnose na poznavanje pravnih propisa kojima se uređuju izabrana radna prava u Hrvatskoj (28 pitanja) te njihovi stavovi o članstvu i djelovanju sindikata (3 pitanja). U trećem dijelu upitnika (pitanje otvorenog tipa) ispitanici su imali mogućnost iznijeti dodatni komentar na temu istraživanja, zapošljavanja mladih i o stanju na tržištu rada. Ovaj upitnik nije ranije testiran, a za provjeru postoje li odstupanja od distribucije rezultata korišten je

Upitnik je nastao kao rezultat interdisciplinarne suradnje Sindikata Preporod i Pravnog fakulteta u Splitu (Katedre za radno i socijalno pravo i Katedre za sociologiju). 
Kolomogorov-Smirnov test $(Z=0,176, p=0,4325)$ koji pokazuje da se distribucija ne razlikuje statistički značajno od normalne. U pogledu asimetrije, odstupanja od normalne distribucije mjerena su s pomoću dvaju parametara (Skewness=-0,470; Kurtosis=-3,455) koji upućuju na umjerenu asimetriju. Izračunom Cronbachova i Spearman-Brownova koeficijenta pouzdanosti upitnika utvrđena je zadovoljavajuća pouzdanost ( $\alpha=0,856$; $S B=0,826)$. Koeficijent pouzdanosti deset dimenzija znanja je 0,835 , a Spearman-Brownov koeficijent 0,805 što pokazuje zadovoljavajuću pouzdanost.

Poznavanje pravnih propisa kojima se uređuje položaj radnika u Hrvatskoj mjereno je korištenjem upitnika s pitanjima zatvorenog tipa koja su tematski grupirana u dvije kategorije radnih prava: (1) individualna i (2) kolektivna. Individualna prava obuhvaćena su kroz devet tema (zasnivanje radnog odnosa, zaštita trudnica, roditelja i posvojitelja, privremeno zapošljavanje, probni rad, radno vrijeme, odmori i dopusti, prestanak ugovora o radu i zaštita dostojanstva radnika), a kolektivna prava pitanjima o kolektivnim ugovorima, sindikatu i štrajkovima. Zakonodavni okvir na temelju kojeg su izrađena anketna pitanja uključivao je sljedeće pravne izvore: Zakon o radu u $\mathrm{RH}^{3}$ (26 pitanja), Zakon o rodiljnim i roditeljskim potporama (jedno pitanje) te Zakon o tržištu rada (jedno pitanje). Na svih 28 pitanja ispitanici su trebali odabrati samo jedan odgovor i samo je jedan odgovor bio točan. Odgovori na pitanja zatvorenog tipa konstruirani su tako da učenicima nude minimalno četiri, a maksimalno šest mogućih odgovora unutar kojih je na svakom pitanju bila ponuđena i mogućnost odgovora "ne znam/nisam siguran/na" kako bi se izbjeglo nasumično opredjeljivanje za neki od ponuđenih odgovora.

\subsection{Uzorak}

Uzorak ( $\mathrm{N}=1102)$ je prigodan i razmjerno stratificiran kontroliranjem varijable spol. Ovako postavljen prigodni uzorak posljedica je dostupnosti ispitanika i realnih mogućnosti aplikativnog projekta u okviru kojeg je istraživanje provedeno. Tako je uzorak određen iz škola koje su članice sindikata Preporod.

Od ukupno 453 redovne srednje strukovne škole u Hrvatskoj u uzorku su zastupljene 54 srednje strukovne škole $(12 \%)$ trogodišnjih, četverogodišnjih i petogodišnjih strukovnih programa ${ }^{4}$ (tehnički, medicinski, obrtnički, industrijski) iz 30

3 Stariji Zakon o radu (NN 149/09, 61/11, 73/13) bio je osnova za izradu anketnih pitanja, a nakon provedbe anketnog istraživanja, od 01. 01. 2020., na snagu je stupio novi, trenutačno aktualan Zakon o radu (NN 93/14, 127/17, 98/19.). Budući da su pravni propisi čije je poznavanje predmetom ovog istraživanja u sadržajnom smislu ostali isti, izmjena ZOR-a nije utjecala na aktualnost i točnost pitanja o poznavanju pravnih propisa iz područja radnih prava u Hrvatskoj.

4 U RH strukovni programi mogu trajati od jedne do pet godina, što ovisi o vrsti obrazovnog programa, 
naselja u Hrvatskoj. U svakoj školi uključenoj u istraživanje završni razredi u kojima je provedeno anketiranje odabrani su po slučaju.

Od ukupnog broja 24084 maturanata srednjih strukovnih škola u Hrvatskoj (učenika 15 316, a učenica 8768) (MZO, 2021) u ovom istraživanju sudjelovalo je njih 1102 iz svih regija u Hrvatskoj (učenika 606; učenica 496). U uzorku su više zastupljeni učenici $(55 \%)$ u odnosu na učenice $(45 \%)$, što je očekivano s obzirom na veću zastupljenost muškaraca u strukovnim školama i u općoj populaciji maturanata u kojoj je učenika približno $63,6 \%$, a učenica $36,4 \%$. Veća zastupljenost učenica u našem uzorku u odnosu na opću populaciju učenica u strukovnim školama objašnjava se i većom zastupljenošću četverogodišnjih tehničkih programa $(88,4 \%)$ u uzorku u odnosu na industrijske i obrtničke trogodišnje programe koji su u uzorku podzastupljeni (9\%) u odnosu na njihovu zastupljenost u općoj populaciji strukovnih škola, a što također predstavlja ograničenje realiziranog uzorka. S obzirom na to da je u trogodišnjim školama veći broj učenika u odnosu na učenice, ravnomjernija zastupljenost trogodišnjih škola u uzorku povećala bi i broj učenika u uzorku u odnosu na učenice, što bi više odgovaralo stanju u populaciji. lako uzorak ima određenih ograničenja u zaključivanju na razini populacije i kao takav nije reprezentativan, smatramo da rezultati ipak imaju određenu spoznajnu i praktičku vrijednost te mogu poslužiti za buduća istraživanja o temi koja nije dovoljno zastupljena u Hrvatskoj budući da je uzorak dovoljno velik i geografski dovoljno disperziran. U istraživanju su zastupljene sve regije u Hrvatskoj ${ }^{5}$, a prema mjestu stanovanja najviše ispitanika živi u naseljima do 10000 stanovnika (32,8\%), zatim u naseljima sa 10000 do 100000 stanovnika $(28,9 \%)$, Gradu Zagrebu $(27,1 \%)$ te u gradovima s više od 100000 stanovnika (10,6\%).

Socioekonomski i obrazovni status roditelja važni su prediktori kod odabira srednje škole i obrazovnog uspjeha učenika. Kad je riječ o obrazovanju roditelja, rezultati ovog istraživanja potvrđuju i rezultate ranije provedenih istraživanja među mladima u Hrvatskoj o niskoj razini društvene mobilnosti u hrvatskom društvu (Gvozdanović i dr., 2019: 7-8), odnosno da obrazovni status roditelja utječe i na obrazovanje njihove djece i odabir srednje škole (Baranović, 2015; Markočić Dekanić i dr., 2019). Tako su među ispitanicima najzastupljeniji učenici čiji su roditelji

odnosno strukovnog kurikula. Ovim istraživanjem nisu obuhvaćeni strukovni programi koji traju do dvije godine nakon kojih učenici stječu nižu razinu srednjeg obrazovanja. Istraživanje je provedeno samo u srednjim strukovnim školama u trajanju od tri, četiri ili pet godina nakon kojih učenici stječu srednju stručnu spremu.

$5 \quad U$ budućim istraživanjima zastupljenost regija trebala bi biti ravnomjernija. U ovom uzorku zastupljene su četiri regije unutar kojih su najzastupljeniji ispitanici iz Grada Zagreba $(30,4 \%)$, Sjeverne Hrvatske (29,1\%), zatim iz Jadranske (26,9\%) te Panonske Hrvatske (13,3\%). U uzorku nisu zastupljene županije: Varaždinska, Požeško-slavonska, Brodsko-posavska i Osječkobaranjska. 
završili srednjoškolsko obrazovanje (67,6\% očeva u odnosu na $64 \%$ majki), dok visoki stupanj obrazovanja imaju više majke (20\%) u odnosu na očeve $(17,2 \%)$. Među ispitanicima $65,7 \%$ je do ispunjavanja upitnika već imalo radnog iskustva u obliku sezonskog rada, povremenog obavljanja poslova i sl.

Budući da se istraživanje provodilo u srednjim školama, od nadležnog ministarstva i roditelja zatraženo je odobrenje za sudjelovanje učenika. Nakon pozitivnog odgovora, ispitanici su upitnik ispunjavali dobrovoljno tijekom školskog sata. Upitnik je distribuiran preko nositelja projekta Sindikata Preporod i sindikalnih povjerenika u školama u kojima djeluje Sindikat.

Tablica 1. Sociodemografska i obrazovna struktura ispitanika i obrazovanje roditelja

\begin{tabular}{|c|c|c|c|}
\hline & & $\mathbf{f}$ & $\%$ \\
\hline \multirow{2}{*}{ Spol } & muški & 606 & 55 \\
\hline & ženski & 496 & 45 \\
\hline \multirow{6}{*}{ Godina rođenja } & 2000. & 726 & 65,9 \\
\hline & 2001. & 272 & 24,7 \\
\hline & 1999. & 75 & 6,8 \\
\hline & 2002. & 16 & 1,5 \\
\hline & 1998. & 7 & 0,6 \\
\hline & bez odgovora & 6 & 0,54 \\
\hline \multirow{5}{*}{ Naselja } & do 10000 st. & 361 & 32,8 \\
\hline & od 10000 do 100000 st. & 319 & 28,9 \\
\hline & preko 100000 st. & 117 & 10,6 \\
\hline & Grad Zagreb & 299 & 27,1 \\
\hline & bez odgovora & 6 & 0,54 \\
\hline \multirow{4}{*}{$\begin{array}{l}\text { Program strukovne } \\
\text { škole }\end{array}$} & četverogodišnji & 974 & 88,4 \\
\hline & trogodišnji & 99 & 9 \\
\hline & petogodišnji & 27 & 2,5 \\
\hline & bez odgovora & 2 & 0,18 \\
\hline \multirow{5}{*}{ Školski uspjeh } & vrlo dobar & 620 & 56,3 \\
\hline & dobar & 267 & 24,2 \\
\hline & odličan & 187 & 17 \\
\hline & dovoljan & 9 & 0,8 \\
\hline & bez odgovora & 19 & 1,72 \\
\hline
\end{tabular}




\begin{tabular}{llcc}
\hline & & $\mathbf{f}$ & \% \\
\hline OBRAZOVANJE RODITELJA & & \\
\hline \multirow{4}{*}{ Majka } & (ne)završena osnovna škola & 60 & 5,4 \\
\cline { 2 - 4 } & srednjoškolsko obrazovanje & $\mathbf{7 0 5}$ & $\mathbf{6 4}$ \\
\cline { 2 - 4 } & viša škola/fakultet & 220 & 20 \\
\cline { 2 - 4 } & magisterij/doktorat & 35 & 3,2 \\
\cline { 2 - 4 } & ne znaju, nisu sigurni/e & 51 & 4,6 \\
\cline { 2 - 4 } & bez odgovora & 31 & 2,81 \\
\hline \multirow{4}{*}{ Otac } & sre)završena osnovna škola & 46 & 4,2 \\
\cline { 2 - 4 } & viša škola/fakultet & $\mathbf{7 4 5}$ & $\mathbf{6 7 , 6}$ \\
\cline { 2 - 4 } & magisterij/doktorat & 32 & 17,2 \\
\cline { 2 - 4 } & ne znaju, nisu sigurni/e & 60 & 5,5 \\
\cline { 2 - 4 } & bez odgovora & 30 & 2,72 \\
\hline
\end{tabular}

\section{PRIKAZ REZULTATA ISTRAŽIVANJA}

Poznavanje pravnih propisa i prava iz radnog odnosa ispitivalo se $s$ pomoću 28 varijabli koje su grupirane u deset dimenzija: 1) zasnivanje radnog odnosa, 2) zaštita prava trudnica, roditelja i posvojitelja, 3) privremeno zapošljavanje, 4) probni rad, 5) radno vrijeme, 6) prava u vezi odmora i dopusta, 7) plaća, 8) prestanak ugovora o radu, 9) zaštita dostojanstva radnika i 10) kolektivna prava. Spomenutih deset dimenzija zajedno tvore ukupan indeks poznavanja odabranih radnih prava.

$\mathrm{U}$ obradi podataka primijenjene su metode deskriptivne statistike i regresijska analiza.

Sva pitanja kojima se ispitivala razina znanja imala su više ponuđenih odgovora, a samo je jedan bio točan. Nijedan ispitanik nije točno odgovorio na sva pitanja, a maksimum ostvarenih točnih odgovora je 25 od mogućih 28 . U prosjeku, ispitanici su točno odgovorili na trinaest pitanja. Najvišu razinu znanja ispitanici su pokazali u poznavanju prava iz zasnivanja radnog odnosa jer su u prosjeku točno odgovorili na dva od pet postavljena pitanja ( $M=2,39)$ te na dimenziji prava u vezi odmora i dopusta $(M=2,16)$. Većina ispitanika $(84,9 \%)$ upoznata je $s$ činjenicom da ugovor o radu mora biti sklopljen u pisanom obliku te da se u RH može zaposliti osoba mlađa od 18 godina uz ovlaštenje zakonskog zastupnika i završeno obvezno osnovno obrazovanje $(54,4 \%)$. Unutar te dimenzije nižu razinu znanja ispitanici su pokazali na pitanjima koja se odnose na obveze i odnos poslodavaca prema 
radniku. Tako nešto više od polovine ispitanika ne zna da pri zapošljavanju radnici nisu dužni dati poslodavcu podatke koji nisu u neposrednoj vezi s radnim odnosom (npr. planiranje trudnoće) (57\%). Također, većina ispitanika $(75,4 \%)$ ne zna da je najdulje razdoblje uzastopnog sklapanja ugovora o radu na određeno vrijeme tri godine, a samo trećina ispitanika $(31,5 \%)$ upoznata je s obvezom poslodavca koja se odnosi na zakonski rok u kojem je dužan dostaviti radniku primjerak prijave na obvezno mirovinsko i zdravstveno osiguranje.

Budući da ispitanici pripadaju skupini mladih za koje je očekivati da će se, barem dio njih, po završetku srednje škole uključiti na tržište rada i planirati zasnivanje obitelji, poznavanje propisa koji se odnose na zaštitu trudnica od otkaza i pravo očeva na roditeljski dopust čini nam se važnim za ostvarivanje prava na dostojanstven rad i jačanje svijesti o ravnopravnosti i egalitarnijim praksama roditeljstva. No, manje od polovine ispitanika $(41,2 \%)$ upoznato je s pravima žena u slučaju zapošljavanja i/ili raskida radnog odnosa uslijed trudnoće, odnosno pitanje koje se odnosi za poznavanje prava u vezi zaštite trudnica, roditelja i posvojitelja je među pitanjima na kojima je postignuto najmanje točnih odgovora. Nešto višu razinu znanja ispitanici su pokazali u poznavanju prava koje se odnosi na očeve, odnosno više od polovine ispitanika upoznato je s tim da očevi imaju zakonom propisano pravo na roditeljski dopust $(59,4 \%)$.

Na svim ostalim dimenzijama ispitanici su u prosjeku znali točno odgovoriti na jedno pitanje. Dimenzija prava u slučaju prestanka ugovora o radu sadržava četiri pitanja, a ispitanici su u prosjeku točno odgovorili na jedno $(M=1,30)$. Najviše ispitanika $(60,4 \%)$ upoznato je sa zakonskom obvezom poslodavca prema radnicima uslijed raskida ugovora o radu prema kojem otkaz mora biti obrazložen i dostavljen u pisanom obliku. Najmanji postotak točnih odgovora u sklopu te dimenzije ostvaren je na pitanju o pravima radnika na naknadu za nezaposlenost u slučaju sporazumnog raskida ugovora o radu (11,6\% točnih odgovora).

Pitanja koja se odnose na sindikate i štrajk pripadaju dimenziji kolektivnih prava na kojoj su ispitanici u prosjeku točno odgovorili na jedno od četiri pitanja ( $M$ $=1,44)$. Kad je riječ o proširenju prava radnika, trećina ispitanika zna da se kolektivnim ugovorom u pravilu mogu ugovoriti veća prava u odnosu na prava iz ugovora o radu. Točnost odgovora na pitanja koja se odnose na sindikat pokazuju da učenici/e nisu dovoljno upoznati s područjem djelovanja sindikata. Tako $26,7 \%$ ispitanika zna tko može u Hrvatskoj pokrenuti sindikat, a njih samo 6,7\% zna da upravo sindikat može organizirati i pokrenuti štrajk. U okviru te dimenzije, najviše ispitanika $(71,7 \%)$ točno je odgovorilo da su razlozi pokretanja štrajka promicanje gospodarskih i socijalnih interesa radnika te neisplata plaća. 
Tablica 2. Deskriptivna statistika indeksa znanja o odabranim radnim pravima

\begin{tabular}{|c|c|c|c|c|c|}
\hline & Minimum & Maksimum & $\begin{array}{l}\text { Prosjek/ } \\
\text { aritmetička } \\
\text { sredina }\end{array}$ & Medijan & SD \\
\hline Zasnivanje radnog odnosa* & 0 & 5 & 2,39 & 2 & 1,121 \\
\hline $\begin{array}{l}\text { Zaštita trudnica, roditelja i } \\
\text { posvojitelja }\end{array}$ & 0 & 1 & ,41 & 0 & ,493 \\
\hline Probni rad & 0 & 2 & 1,09 & 1 & ,715 \\
\hline Privremeno zapošljavanje & 0 & 1 &, 40 & 0 & ,489 \\
\hline Radno vrijeme & 0 & 3 & 1,19 & 1 & ,893 \\
\hline Odmori i dopusti & 0 & 4 & 2,16 & 2 & 1,168 \\
\hline Plaća radnika/radnica & 0 & 2 & 1,30 & 1 & ,724 \\
\hline Prestanak ugovora o radu & 0 & 4 & 1,30 & 1 & ,953 \\
\hline Zaštita dostojanstva radnika & 0 & 2 & 1,12 & 1 & ,648 \\
\hline Kolektivna radna prava & 0 & 4 & 1,44 & 1 & ,948 \\
\hline Indeks ukupnog znanja ${ }^{* *}$ & 0 & 25 & 12,90 & 13 & 4,551 \\
\hline
\end{tabular}

Rezultati ukupnog znanja o odabranim radnim pravima upućuju na relativno slabo poznavanje i nisku razinu pravne pismenosti iz područja radnih prava među ispitanim maturantima srednjih strukovnih škola u Hrvatskoj.

Osim ukupnog znanja, ovim su se istraživanjem nastojale istražiti i razlike među ispitanicima s obzirom na varijable spola, mjesta stanovanja, srednjoškolskog uspjeha, i radnog iskustva (Tablica 3.). Za testiranje statističke značajnosti razlike u prosječnim rezultatima korišten je t-test i ANOVA. 
Tablica 3. Usporedba prosječnih vrijednosti po odabranim dimenzijama radnih prava prema spolu, mjestu stanovanja, školskom uspjehu i radnom iskustvu

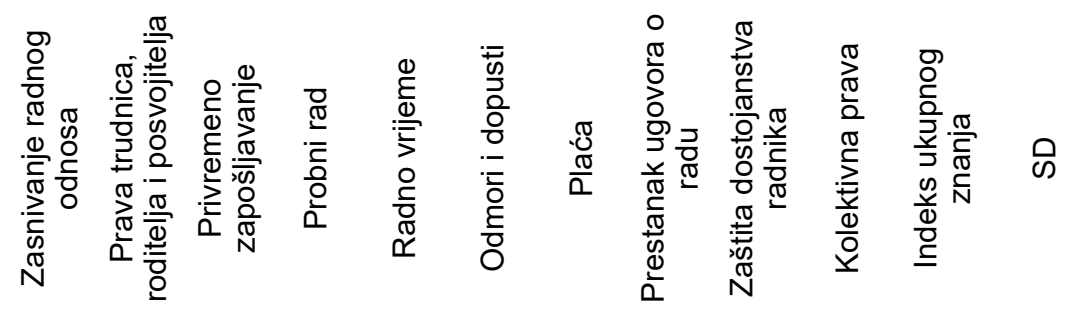

\begin{tabular}{|c|c|c|c|c|c|c|c|c|c|c|c|c|c|}
\hline \multirow{2}{*}{ Spol } & ženski & 2,48 & ,46 & 1,22 & ,41 & 1,22 & 2,33 & 1,43 & 1,38 & 1,19 & 1,55 & 13,78 & 4,004 \\
\hline & muški & 2,32 & ,38 & ,98 & ,39 & 1,17 & 2,01 & 1,20 & 1,22 & 1,06 & 1,34 & 12,13 & 4,856 \\
\hline \multirow{4}{*}{ Naselje } & $\begin{array}{l}\text { do } 10000 \\
\text { st. }\end{array}$ & 2,28 & ,43 & 1,16 & ,39 & 1,19 & 2,28 & 1,43 & 1,30 & 1,15 & 1,44 & 13,04 & 4,412 \\
\hline & $\begin{array}{l}10 \text { tis. - } \\
100 \text { tis. }\end{array}$ & 2,48 & ,41 & 1,06 & ,45 & 1,19 & 2,17 & 1,28 & 1,40 & 1,17 & 1,55 & 13,32 & 4,126 \\
\hline & $\begin{array}{l}\text { preko } \\
100000\end{array}$ & 2,31 & ,38 & 1,07 & ,31 & ,91 & 1,91 & 1,17 & 1,13 & 1,03 & 1,23 & 11,79 & 5,504 \\
\hline & $\begin{array}{l}\text { Grad } \\
\text { Zagreb }\end{array}$ & 2,48 & ,42 & 1,04 & ,39 & 1,30 & 2,09 & 1,24 & 1,26 & 1,08 & 1,14 & 12,76 & 4,716 \\
\hline \multirow{4}{*}{$\begin{array}{l}\text { Školski } \\
\text { uspjeh }\end{array}$} & odličan & 2,56 & ,49 & 1,19 & ,43 & 1,25 & 2,29 & 1,44 & 1,40 & 1,25 & 1,66 & 14,04 & 4,438 \\
\hline & vrlo dobar & 2,38 & ,42 & 1,11 & ,40 & 1,21 & 2,15 & 1,29 & 1,32 & 1,13 & 1,44 & 12,97 & 4,471 \\
\hline & dobar & 2,34 & ,35 & 1,00 & ,39 & 1,14 & 2,06 & 1,25 & 1,20 & 1,03 & 1,32 & 12,09 & 4,575 \\
\hline & dovoljan & 1,71 & ,33 & ,78 & , 10 & 1,23 & 1,44 & ,88 & ,63 & ,63 & 67 & 10,33 & 4,320 \\
\hline \multirow{2}{*}{$\begin{array}{l}\text { Radno } \\
\text { iskustvo }\end{array}$} & imaju & 2,44 & ,42 & 1,11 & ,41 & 1,21 & 2,17 & 1,34 & 1,31 & 1,12 & 1,44 & 13,08 & 4,501 \\
\hline & nemaju & 2,31 & ,42 & 1,06 & ,37 & 1,17 & 2,17 & 1,25 & 1,27 & 1,23 & 1,46 & 12,68 & 4,669 \\
\hline
\end{tabular}

Razlike u znanju i razini pravne pismenosti o pravnim propisima iz radnog prava postoje među ispitanicima i to s obzirom na varijable spol, mjesto stanovanja i školski uspjeh. No, nema razlika u znanju između ispitanika koji imaju radno iskustvo i onih koji dosad nisu bili aktivni na tržištu rada.

Razlike u prosječnim rezultatima s obzirom na varijablu spola pokazuju da su učenice ostvarile višu razinu znanja od učenika na svim dimenzijama znanja o pravnim propisima iz područja radnog prava (Tablica 4). lako su razlike među ispitanicima po svim dimenzijama znanja o pravnim propisima iz radnog prava male, 
statistički su značajne na nekim dimenzijama znanja. Na dvije od ukupno deset dimenzija znanja statističke razlike po spolu nisu značajne (privremeno zapošljavanje i poznavanje radnog vremena). Na dimenziji indeksa ukupnog znanja utvrđeno je da postoji statistički značajna razlika s obzirom na spol, odnosno da su učenice ostvarile značajno viši prosjek točnih odgovora od učenika.

Tablica 4. Razlike s obzirom na varijablu spola

\begin{tabular}{|c|c|c|c|c|c|c|}
\hline Dimenzije znanja & Spol & M & SD & $\mathrm{t}$ & df & $\mathrm{p}$ \\
\hline \multirow{2}{*}{ Zasnivanje radnog odnosa } & $\check{Z}$ & 2,48 & 1,022 & \multirow{2}{*}{2,315} & \multirow{2}{*}{1071} & \multirow{2}{*}{0,021} \\
\hline & $M$ & 2,32 & 1,191 & & & \\
\hline \multirow{2}{*}{$\begin{array}{l}\text { Zaštita trudnica, roditelja i } \\
\text { posvojitelja }\end{array}$} & Ž & ,46 & ,499 & \multirow{2}{*}{2,660} & \multirow{2}{*}{1094} & \multirow{2}{*}{0,008} \\
\hline & $M$ &, 38 & ,485 & & & \\
\hline \multirow{2}{*}{ Probni rad } & Ž & 1,22 & ,692 & \multirow{2}{*}{5,834} & \multirow{2}{*}{1093} & \multirow{2}{*}{0,001} \\
\hline & $M$ & ,98 &, 715 & & & \\
\hline \multirow{2}{*}{ Privremeno zapošljavanje } & $\check{Z}$ & ,41 & ,492 & \multirow{2}{*}{,722 } & \multirow{2}{*}{1092} & \multirow{2}{*}{0,470} \\
\hline & $M$ & ,39 & ,487 & & & \\
\hline \multirow{2}{*}{ Radno vrijeme } & $\check{Z}$ & 1,22 & ,847 & \multirow{2}{*}{, 786} & \multirow{2}{*}{1068} & \multirow{2}{*}{0,432} \\
\hline & $M$ & 1,17 & ,929 & & & \\
\hline \multirow{2}{*}{ Odmori i dopusti } & $\check{Z}$ & 2,33 & 1,098 & \multirow{2}{*}{4,586} & \multirow{2}{*}{1078} & \multirow{2}{*}{0,001} \\
\hline & $M$ & 2,01 & 1,205 & & & \\
\hline \multirow{2}{*}{ Plaća radnika/radnica } & $\check{Z}$ & 1,43 & 671 & \multirow{2}{*}{5,364} & \multirow{2}{*}{1082} & \multirow{2}{*}{0,000} \\
\hline & $M$ & 1,20 & ,749 & & & \\
\hline \multirow{2}{*}{ Prestanak ugovora o radu } & $\check{Z}$ & 1,38 & ,947 & \multirow{2}{*}{2,769} & \multirow{2}{*}{1081} & \multirow{2}{*}{0,006} \\
\hline & $M$ & 1,22 & ,952 & & & \\
\hline \multirow{2}{*}{ Zaštita dostojanstva radnika } & $\check{Z}$ & 1,19 &, 70 & \multirow{2}{*}{3,308} & 1015 & \\
\hline & $M$ & 1,06 & ,701 & & 1040 & 0,001 \\
\hline Kolektivna radna i socijalna & Ž & 1,55 & ,920 & 3531 & 1057 & 0001 \\
\hline prava & $M$ & 1,34 & ,962 & ו וטנ, & 1001 & 0,001 \\
\hline & Ž & 13,78 & 4,004 & & & \\
\hline mueks ukupliog ziranja & $M$ & 12,13 & 4,856 & $0,0<2$ & 500 & 0,000 \\
\hline
\end{tabular}


S obzirom na mjesto stanovanja u kojem ispitanici žive, uočena je statistički značajna razlika s obzirom na ukupno znanje (Tablica 5.). Iz rezultata istraživanja uočavamo da su ispitanici s prebivalištem u manjim naseljima (do 10000 stanovnika) i gradovima do 100000 stanovnika ostvarili značajno viši prosjek točnih odgovora, odnosno višu razinu znanja od učenika s prebivalištem u gradovima s više od 100 000 stanovnika i u Gradu Zagrebu.

Tablica 5. Razlike prema mjestu stanovanja

\begin{tabular}{|c|c|c|c|c|c|c|}
\hline Dimenzije znanja & Mjesto stanovanja & M & SD & $\mathrm{F}$ & df & $\mathrm{p}$ \\
\hline \multirow{4}{*}{$\begin{array}{l}\text { Zasnivanje radnog } \\
\text { odnosa }\end{array}$} & do 10000 st. & 2,28 & 1,128 & \multirow{4}{*}{1,989} & \multirow{4}{*}{4} & \multirow{4}{*}{0,094} \\
\hline & $10000-100000$ & 2,48 & 1,024 & & & \\
\hline & više od 100000 st. & 2,31 & 1,178 & & & \\
\hline & Grad Zagreb & 2,48 & 1,177 & & & \\
\hline \multirow{4}{*}{$\begin{array}{l}\text { Zaštita trudnica, } \\
\text { roditelja i posvojitelja }\end{array}$} & do 10000 st. &, 43 & ,496 & \multirow{4}{*}{,321 } & \multirow{4}{*}{4} & \multirow{4}{*}{0,864} \\
\hline & $10000-100000$ & ,42 & ,492 & & & \\
\hline & više od 100000 st. & ,38 & ,486 & & & \\
\hline & Grad Zagreb & ,42 & ,494 & & & \\
\hline \multirow{4}{*}{ Probni rad } & do 10000 st. & 1,16 & ,704 & \multirow{4}{*}{1,324} & \multirow{4}{*}{4} & \multirow{4}{*}{0,259} \\
\hline & $10000-100000$ & 1,06 & ,726 & & & \\
\hline & više od 100000 st. & 1,07 & ,719 & & & \\
\hline & Grad Zagreb & 1,04 & ,718 & & & \\
\hline \multirow{4}{*}{$\begin{array}{l}\text { Privremeno } \\
\text { zapošljavanje }\end{array}$} & do 10000 st. & ,39 & ,488 & \multirow{4}{*}{2,262} & \multirow{4}{*}{4} & \multirow{4}{*}{0,061} \\
\hline & $10000-100000$ & ,45 & ,498 & & & \\
\hline & više od 100000 st. & 31 & ,464 & & & \\
\hline & Grad Zagreb &, 39 & ,489 & & & \\
\hline \multirow{4}{*}{ Radno vrijeme } & do 10000 st. & 1,19 & 875 & \multirow{4}{*}{3,945} & \multirow{4}{*}{4} & \multirow{4}{*}{0,003} \\
\hline & $10000-100000$ & 1,19 & ,901 & & & \\
\hline & više od 100000 st. & ,91 & 874 & & & \\
\hline & Grad Zagreb & 1,30 & 895 & & & \\
\hline \multirow{4}{*}{ Odmori i dopusti } & do 10000 st. & 2,28 & 1,149 & \multirow{4}{*}{2,756} & \multirow{4}{*}{4} & \multirow{4}{*}{0,027} \\
\hline & $10000-100000$ & 2,17 & 1,141 & & & \\
\hline & više od 100000 st. & 1,91 & 1,362 & & & \\
\hline & Grad Zagreb & 2,09 & 1,132 & & & \\
\hline
\end{tabular}




\begin{tabular}{|c|c|c|c|c|c|c|}
\hline Dimenzije znanja & Mjesto stanovanja & M & SD & $\mathrm{F}$ & df & $\mathrm{p}$ \\
\hline \multirow{4}{*}{ Plaće radnika i radnica } & do 10000 st. & 1,43 & ,707 & \multirow{4}{*}{4,549} & \multirow{4}{*}{4} & \multirow{4}{*}{0,001} \\
\hline & $10000-100000$ & 1,28 & ,706 & & & \\
\hline & više od 100000 st. & 1,17 & ,752 & & & \\
\hline & Grad Zagreb & 1,24 & ,737 & & & \\
\hline \multirow{4}{*}{$\begin{array}{l}\text { Prestanak ugovora o } \\
\text { radu }\end{array}$} & do 10000 st. & 1,30 & ,951 & \multirow{4}{*}{1,993} & \multirow{4}{*}{4} & \multirow{4}{*}{0,093} \\
\hline & $10000-100000$ & 1,40 & ,955 & & & \\
\hline & više od 100000 st. & 1,13 & ,954 & & & \\
\hline & Grad Zagreb & 1,26 & 950 & & & \\
\hline \multirow{4}{*}{$\begin{array}{l}\text { Zaštita dostojanstva } \\
\text { radnika }\end{array}$} & do 10000 st. & 1,15 & ,613 & \multirow{4}{*}{1,388} & \multirow{4}{*}{4} & \multirow{4}{*}{0,236} \\
\hline & $10000-100000$ & 1,17 & 635 & & & \\
\hline & $10000-100000$ & 1,03 & ,713 & & & \\
\hline & Grad Zagreb & 1,08 & ,681 & & & \\
\hline \multirow{4}{*}{ Kolektivna radna prava } & do 10000 st. & 1,44 & ,937 & \multirow{4}{*}{3,024} & \multirow{4}{*}{4} & \multirow{4}{*}{0,017} \\
\hline & $10000-100000$ & 1,55 & ,965 & & & \\
\hline & više od 100000 st. & 1,23 & ,955 & & & \\
\hline & Grad Zagreb & 1,41 & ,910 & & & \\
\hline \multirow{4}{*}{$\begin{array}{l}\text { Indeks ukupnog } \\
\text { znanja }\end{array}$} & do 10000 st. & 13,04 & 4,412 & \multirow{4}{*}{2,474} & \multirow{4}{*}{4} & \multirow{4}{*}{0,040} \\
\hline & $10000-100000$ & 13,32 & 4,126 & & & \\
\hline & više od 100000 st. & 11,79 & 5,504 & & & \\
\hline & Grad Zagreb & 12,76 & 4,716 & & & \\
\hline
\end{tabular}

S obzirom na srednjoškolski uspjeh, među ispitanicima su uočene razlike u prosječnim rezultatima na svim dimenzijama znanja (Tablica 6.). Ispitanici koji su ostvarili odličan uspjeh u školi pokazali su višu razinu znanja na svim dimenzijama. Najnižu razinu znanja pokazali su učenici/e koji ostvaruju dovoljan uspjeh u školi nakon kojih slijede ispitanici koji ostvaruju dobar uspjeh. Učenici/e koji su ostvarili odličan uspjeh postigli su najveću razinu znanja po svim dimenzijama i na indeksu ukupnog znanju o radničkim pravima, što upućuje na povezanost školskog uspjeha i razine znanja, odnosno pravne pismenosti u području odabranih radnih prava. 
Tablica 6. Razlike s obzirom na školski uspjeh

\begin{tabular}{|c|c|c|c|c|c|c|}
\hline Dimenzije znanja & Školski uspjeh & $M$ & SD & $\mathrm{F}$ & $\mathrm{df}$ & $\mathrm{p}$ \\
\hline \multirow{4}{*}{$\begin{array}{l}\text { Zasnivanje radnog } \\
\text { odnosa }\end{array}$} & dovoljan & 1,71 & 1,604 & \multirow{4}{*}{1,954} & \multirow{4}{*}{5} & \multirow{4}{*}{0,083} \\
\hline & dobar & 2,34 & 1,202 & & & \\
\hline & vrlo dobar & 2,38 & 1,091 & & & \\
\hline & odličan & 2,56 & 1,062 & & & \\
\hline \multirow{4}{*}{$\begin{array}{l}\text { Zaštita trudnica, } \\
\text { roditelja i } \\
\text { posvojitelja }\end{array}$} & dovoljan & ,33 &, 5 & \multirow{4}{*}{2,217} & \multirow{4}{*}{5} & \multirow{4}{*}{0,051} \\
\hline & dobar & ,35 & ,477 & & & \\
\hline & vrlo dobar & ,42 & ,494 & & & \\
\hline & odličan & ,49 &, 501 & & & \\
\hline \multirow{4}{*}{ Probni rad } & dovoljan & ,78 & 667 & \multirow{4}{*}{3,754} & \multirow{4}{*}{5} & \multirow{4}{*}{0,002} \\
\hline & dobar & 1,0 & ,723 & & & \\
\hline & vrlo dobar & 1,11 & ,721 & & & \\
\hline & odličan & 1,19 & 670 & & & \\
\hline \multirow{4}{*}{$\begin{array}{l}\text { Privremeno } \\
\text { zapošljavanje }\end{array}$} & dovoljan & ,02 & ,01 & \multirow{4}{*}{1,975} & \multirow{4}{*}{5} & \multirow{4}{*}{0,080} \\
\hline & dobar & ,488 & ,488 & & & \\
\hline & vrlo dobar & ,491 & ,491 & & & \\
\hline & odličan & ,496 & ,496 & & & \\
\hline \multirow{4}{*}{ Radno vrijeme } & dovoljan & 1,25 & ,886 & \multirow{4}{*}{,896 } & \multirow{4}{*}{5} & \multirow{4}{*}{0,483} \\
\hline & dobar & 1,14 & ,888 & & & \\
\hline & vrlo dobar & 1,21 & ,882 & & & \\
\hline & odličan & 1,23 & ,940 & & & \\
\hline \multirow{4}{*}{ Odmori i dopusti } & dovoljan & 1,44 & 1,333 & \multirow{4}{*}{3,312} & \multirow{4}{*}{5} & \multirow{4}{*}{0,006} \\
\hline & dobar & 2,06 & 1,155 & & & \\
\hline & vrlo dobar & 2,15 & 1,146 & & & \\
\hline & odličan & 2,39 & 1,199 & & & \\
\hline \multirow{4}{*}{$\begin{array}{l}\text { Plaće radnika i } \\
\text { radnica }\end{array}$} & dovoljan & 88 & ,354 & \multirow{4}{*}{2,438} & \multirow{4}{*}{5} & \multirow{4}{*}{0,033} \\
\hline & dobar & 1,25 & ,739 & & & \\
\hline & vrlo dobar & 1,29 & ,725 & & & \\
\hline & odličan & 1,44 & ,684 & & & \\
\hline
\end{tabular}




\begin{tabular}{|c|c|c|c|c|c|c|}
\hline Dimenzije znanja & Školski uspjeh & M & SD & $\mathrm{F}$ & $d f$ & $\mathrm{p}$ \\
\hline \multirow{4}{*}{$\begin{array}{l}\text { Prestanak ugovora } \\
\text { o radu }\end{array}$} & dovoljan & ,63 & ,744 & \multirow{4}{*}{1,878} & \multirow{4}{*}{5} & \multirow{4}{*}{0,096} \\
\hline & dobar & 1,20 & ,951 & & & \\
\hline & vrlo dobar & 1,32 & ,955 & & & \\
\hline & odličan & 1,40 & ,931 & & & \\
\hline \multirow{4}{*}{$\begin{array}{l}\text { Zaštita } \\
\text { dostojanstva } \\
\text { radnika }\end{array}$} & dovoljan & ,63 &, 744 & \multirow{4}{*}{4,429} & \multirow{4}{*}{4} & \multirow{4}{*}{0,001} \\
\hline & dobar & 1,03 & ,656 & & & \\
\hline & vrlo dobar & 1,13 & ,641 & & & \\
\hline & odličan & 1,25 &, 634 & & & \\
\hline \multirow{4}{*}{$\begin{array}{l}\text { Kolektivna radna } \\
\text { prava }\end{array}$} & dovoljan & 67 &, 707 & \multirow{4}{*}{4,771} & \multirow{4}{*}{5} & \multirow{4}{*}{0,000} \\
\hline & dobar & 1,32 & ,810 & & & \\
\hline & vrlo dobar & 1,44 &, 974 & & & \\
\hline & odličan & 1,66 & 1,001 & & & \\
\hline \multirow{4}{*}{$\begin{array}{l}\text { Indeks ukupnog } \\
\text { znanja }\end{array}$} & dovoljan & 10,33 & 4,320 & \multirow{4}{*}{5,907} & \multirow{4}{*}{4} & \multirow{4}{*}{0,000} \\
\hline & dobar & 12,09 & 4,575 & & & \\
\hline & vrlo dobar & 12,97 & 4,471 & & & \\
\hline & odličan & 14,04 & 4,388 & & & \\
\hline
\end{tabular}

Razlike u prosječnim rezultatima među učenicima koji imaju radno iskustvo (npr. sezonskog rada, povremenog obavljanja poslova i sl.), u odnosu na one koji ga nemaju, ne postoje ni na jednoj dimenziji znanja kao ni na razini ukupnog znanja o radnim pravima $(t=1,231 ; d f=893 ; p>0,05)$ (vidjeti Tablicu 7 .) 
Tablica 7. Razlike s obzirom na radno iskustvo ispitanika

\begin{tabular}{|c|c|c|c|c|c|c|}
\hline Dimenzije znanja & $\begin{array}{l}\text { Radno } \\
\text { iskustvo }\end{array}$ & M & SD & $\mathrm{t}$ & $\mathrm{df}$ & $\mathrm{p}$ \\
\hline \multirow{2}{*}{$\begin{array}{l}\text { Zasnivanje radnog } \\
\text { odnosa }\end{array}$} & $D a$ & 2,44 & 1,113 & \multirow{2}{*}{1,755} & \multirow{2}{*}{1023} & \multirow{2}{*}{0,080} \\
\hline & $\mathrm{Ne}$ & 2,31 & 1,130 & & & \\
\hline \multirow{2}{*}{$\begin{array}{l}\text { Zaštita trudnica, } \\
\text { roditelja i posvojitelja }\end{array}$} & $D a$ & ,42 & ,494 & \multirow{2}{*}{$-0,100$} & \multirow{2}{*}{1043} & \multirow{2}{*}{0,921} \\
\hline & $\mathrm{Ne}$ & ,42 & ,495 & & & \\
\hline \multirow{2}{*}{ Probni rad } & $D a$ & 1,11 & ,714 & \multirow{2}{*}{1,117} & \multirow{2}{*}{1042} & \multirow{2}{*}{0,264} \\
\hline & $\mathrm{Ne}$ & 1,06 & ,721 & & & \\
\hline \multirow{2}{*}{$\begin{array}{l}\text { Privremeno } \\
\text { zapošljavanje }\end{array}$} & $D a$ & ,41 & ,491 & \multirow{2}{*}{,951 } & \multirow{2}{*}{1042} & \multirow{2}{*}{0,342} \\
\hline & $\mathrm{Ne}$ & ,37 & ,485 & & & \\
\hline \multirow{2}{*}{ Radno vrijeme } & $D a$ & 1,21 & ,908 & \multirow{2}{*}{, 727} & \multirow{2}{*}{1018} & \multirow{2}{*}{0,467} \\
\hline & $\mathrm{Ne}$ & 1,17 & 859 & & & \\
\hline \multirow{2}{*}{ Odmori i dopusti } & $D a$ & 2,17 & 1,162 & \multirow{2}{*}{, 058} & \multirow{2}{*}{1031} & \multirow{2}{*}{0,951} \\
\hline & $\mathrm{Ne}$ & 2,17 & 1,166 & & & \\
\hline \multirow{2}{*}{$\begin{array}{l}\text { Plaće radnika i } \\
\text { radnica }\end{array}$} & $D a$ & 1,34 & ,722 & \multirow{2}{*}{1,946} & \multirow{2}{*}{1032} & \multirow{2}{*}{0,052} \\
\hline & $\mathrm{Ne}$ & 1,25 & ,718 & & & \\
\hline \multirow{2}{*}{$\begin{array}{l}\text { Prestanak ugovora } \\
\text { o radu }\end{array}$} & $D a$ & 1,31 & 977 & \multirow{2}{*}{, 564} & \multirow{2}{*}{1031} & \multirow{2}{*}{0,573} \\
\hline & $\mathrm{Ne}$ & 1,27 & ,918 & & & \\
\hline \multirow{2}{*}{$\begin{array}{l}\text { Zaštita dostojanstva } \\
\text { radnika }\end{array}$} & $D a$ & 1,12 & ,641 & \multirow{2}{*}{$-0,205$} & 997 & 0.838 \\
\hline & $\mathrm{Ne}$ & 1,13 & ,669 & & 991 & 0,838 \\
\hline Kolektivna radna & $D a$ & 1,44 & ,955 & - 397 & 1006 & 0691 \\
\hline prava & $\mathrm{Ne}$ & 1,46 & ,937 & ו & 1000 & ו \\
\hline Indeks ukupnog & $D a$ & 13,08 & 4,501 & 1231 & 893 & 0218 \\
\hline znanja & $\mathrm{Ne}$ & 12,68 & 4,669 & I, I I I & 000 & 0,210 \\
\hline
\end{tabular}

Kako bi se ispitala povezanost između nekih karakteristika ispitanika i indeksa ukupnog znanja, odnosno utjecaj nezavisnih varijabli na razinu znanja o radnim pravima, primijenjena je regresijska analiza, a sažeti rezultati prikazani su u Tablici 8. U regresijski model uključene su sociodemografske i obrazovne karakteristike ispitanika (spol, školski uspjeh, program strukovnog obrazovanja, tip naselja, regija, radno iskustvo) te razina obrazovanja roditelja. Regresijska analiza pokazuje da su prediktorske varijable značajno povezane s razinom znanja o radnim pravi- 
ma, odnosno da postoji utjecaj prediktorskih varijabli na indeks ukupnog znanja o izabranim radnim pravima $(R=0,216 ; p<0,05)$. Regresijski koeficijenti za varijable spola $(\beta=0,148)$, obrazovanja majke $(\beta=0,077)$, radnog iskustva $(\beta=0,065)$ i tipa naselja u kojem ispitanici žive statistički su značajni i imaju doprinos u regresijskom modelu, dok ostale varijable, školskog uspjeha $(\beta=-0,028 ; p=0,344)$, regije $(\beta=0,014 ; p=0,695)$ i stupnja obrazovanja oca $(\beta=-0,012 ; p=0,727)$ nemaju doprinos u regresijskom modelu i nisu statistički značajni. Dakle, razinu ukupnog znanja o radnim pravima značajno predviđaju pojedinačne varijable spola, programa strukovne škole, tipa naselja, radnog iskustva i obrazovanja majke među kojima prema vrijednostima koeficijenata regresije od statistički značajnih varijabli najveći samostalni doprinos ima spol. Tip programa strukovne škole značajno je negativan prediktor razine ukupnog znanja o radnim pravima koji ipak, zbog malih iznosa beta pondera $(\beta=-0,037 ; B=-0,063)$ i podzastupljenosti trogodišnjih programa $u$ uzorku, unatoč statističkoj značajnosti, treba s oprezom uključiti u interpretaciju, jer postoji mogućnost da bi ravnomjernija zastupljenost učenika/ca trogodišnjih programa u uzorku imala veći i/ili manji utjecaj na razinu znanja o izabranim radnim pravima koju su pokazali ispitanici u ovom istraživanju.

Tablica 8. Rezultati regresijske analize za indeks ukupnog znanja

\begin{tabular}{lcc}
\hline Prediktori & Beta koeficijent & Koeficijent regresije $(\beta)$ \\
\hline Spol & 3,968 & $\mathbf{0 , 1 4 8 ^ { * }}$ \\
\hline Tip programa strukovne škole & $-0,063$ & $\mathbf{- 0 , 0 3 7 ^ { * }}$ \\
\hline Školski uspjeh & $-0,531$ & $-0,028$ \\
\hline Naselje & 0,851 & $\mathbf{0 , 0 7 5 ^ { * }}$ \\
\hline Regija & 0,098 & 0,014 \\
\hline Radno iskustvo & 1,496 & $\mathbf{0 , 0 6 5 ^ { * }}$ \\
\hline Razina obrazovanja majke & 0,983 & $\mathbf{0 , 0 7 7 ^ { * }}$ \\
\hline Razina obrazovanja oca & $-0,153$ & $-0,012$ \\
\hline
\end{tabular}

$F=6,661 ; d f=1093 ; p<0,01$

${ }^{*} p<0,05$ 


\section{RASPRAVA I ZAKLJUČCI}

Svrha provedenog istraživanja bila je utvrditi razinu znanja o izabranim radnim pravima među maturantima srednjih strukovnih škola u Hrvatskoj obuhvaćenih istraživanjem. Anketnim upitnikom koji uključuje 28 pitanja zatvorenog tipa ispitivalo se sadržajno znanje pravnih propisa iz radnog prava među skupinom mladih koji su po završetku srednjoškolskog obrazovanja osposobljeni za određeno zanimanje na tržištu rada te koji prema ranije provedenom istraživanju u manjoj mjeri u odnosu na učenike iz gimnazija planiraju studirati (Baranović, 2015).

Maturanti obuhvaćeni istraživanjem točno su odgovorili na manje od polovine pitanja, odnosno u prosjeku su točno odgovorili na 13 od 28 pitanja koja se odnose na poznavanje pravnih propisa i prava iz radnog odnosa. Temeljem tog podatka može se zaključiti da rezultati ukupnog znanja ispitanika upućuju na njihovo relativno slabo poznavanje i nisku razinu pravne pismenosti iz područja radnih prava. Ukupno gledano, najvišu razinu poznavanja pravnih propisa iz područja radnog prava učenici su pokazali na pitanjima koja se odnose na zasnivanje radnog odnosa te na dimenziji prava u vezi odmora i dopusta. Na svim sljedećim ispitivanim dimenzijama (probni rad, radno vrijeme, plaća, zaštita dostojanstva radnika) učenici su pokazali nižu razinu znanja jer su u prosjeku znali odgovoriti na jedno od dva ili jedno od tri pitanja. Najnižu razinu znanja (jedno od četiri postavljena pitanja točno je odgovoreno) učenici su pokazali u pogledu poznavanja prava u vezi prestanka ugovora o radu i informiranosti o kolektivnim radnim pravima te u području privremenog zapošljavanja i zaštite trudnica, roditelja i posvojitelja. Prema "Izvješću Pučke pravobraniteljice za 2019. godinu" najčešći razlozi pritužbi Uredu pravobranitelja odnose se na ostvarivanje prava u vezi prestanka ugovora o radu (npr. pravo na naknadu za vrijeme nezaposlenosti, prava uslijed izvanrednog otkaza i prekida radnog odnosa), neisplata plaća, prekovremeni rad i radno vrijeme kojima su posebno pogođeni zdravstveni djelatnici i radnici u gospodarstvu i obrtu, odnosno sektori i zanimanja u kojima će svoju radnu karijeru ostvariti maturanti obuhvaćeni ovim istraživanjem (Pučki pravobranitelj $\mathrm{RH}, 2020$ ). Zato nam i taj podatak o povredi radnih prava, a s obzirom na ranjivu poziciju mladih na tržištu rada, ukazuje na važnost pravne pismenosti i informiranosti o pravnim propisima.

Poznavanje kolektivnih radnih prava mjereno je s pomoću četiri pitanja koja obuhvaćaju kolektivne ugovore, utemeljenje sindikata te razloge pokretanja i organizaciju štrajka. Iz te grupe pitanja izdvojit ćemo pitanje koje se odnosi na poznavanje temeljne svrhe kolektivnog ugovora kao sporazuma između sindikata i poslodavca kojim se u pravilu mogu ugovoriti veća prava nego ugovorom o radu (ne ulazeći u iznimke, pojedinačne primjere i sl.). To pitanje izdvajamo jer iako je na njega točno odgovorilo $36,7 \%$ učenika, čak $52 \%$ njih se odlučilo za opciju po kojoj "ne znaju 
i/ili nisu sigurni u točan odgovor". Osim toga, samo $6,7 \%$ učenika točno je odgovorilo na pitanje o tome da sindikat može organizirati i pokrenuti štrajk, a gotovo polovina učenika $(43,6 \%)$ ne zna, odnosno nisu sigurni/e bi li se nakon sklapanja radnog odnosa učlanili u sindikat. To su zanimljivi podatci jer pokazuju nesigurnost ispitanih učenika u pogledu poznavanja temeljne svrhe kolektivnih ugovora, a treba naglasiti da su prava približno 650000 radnika u Hrvatskoj regulirana pomoću kolektivnih ugovora (Bagić, 2019: 96). Osim toga, prema podatcima s kraja 2014. godine okvirna procjena razine pokrivenosti radnika kolektivnim ugovorima u Hrvatskoj je približno 53\% (Bagić, 2019: 96). lako postoje velike razlike u pokrivenosti kolektivnim ugovorima u javnom sektoru (oko 88\%), javnim poduzećima (oko $75 \%$ ) i privatnim tvrtkama (oko 36\%), ta je okvirna razina iznad prosjeka ostalih tranzicijskih zemalja (Bagić, 2019: 96). Usporedbe radi, takva je razina pokrivenosti kolektivnim ugovorima na razini Njemačke, gdje ona iznosi otprilike 56\% u 2016., niža od prosječne razine pokrivenosti u sedamnaest članica EU-a gdje za 2015. iznosi približno 69\%, a značajno je niža u odnosu na Dansku, Finsku i Švedsku gdje je ona viša od 80\% za 2016. (Waddington, Müller i Vandaele, 2019: 9-10). Sukladno Zakonu o radu, kolektivnim ugovorima se osim plaća i različitih materijalnih prava (poput dodataka, bonusa, jednokratnih isplata, isplata u posebnim prigodama poput božićnica i sl.), reguliraju i pitanja o radnom vremenu, rasporedu radnog vremena i odmorima, sindikalnom organiziranju itd. Pritom se, ukupno gledano, može zaključiti da su "radni uvjeti i materijalna prava radnika koji su pokriveni kolektivnim ugovorima puno bolja od onih radnika" koji takvim ugovorima nisu pokriveni (Bagić, 2019: 107). Treba naglasiti i to da su rezultati provedenih istraživanja o poznavanju pravnih propisa i prava iz radnog odnosa pokazali da članovi sindikata imaju višu razinu znanja u usporedbi s ostalim radnicima (Meager i dr., 2002: 207), višu razinu svijesti o svojim pravima na radnom mjestu u usporedbi s radnicima koji nisu članovi sindikata (Caseborne i dr., 2006: 48), kao i da članstvo u sindikatu i/ili svjesnost o pravima iz radnog odnosa, u određenoj mjeri, može zaštititi radnika od problema na koje može naići u pogledu njegovih/njezinih radnih prava na radnom mjestu, te može pomoći u rješavanju tih problema (Caseborne i dr., 2006: 1). Stoga, ukoliko se namjerava širiti pravnu pismenost o radnim pravima, učenike bi trebalo informirati i o kolektivnim radnim pravima, sadržaju kolektivnih ugovora, prednostima kolektivnog pregovaranja za radnike itd.

Rezultati ovog istraživanja pokazuju da postoje rodne razlike u razini pokazanog znanja među maturantima obuhvaćenim istraživanjem, jer su učenice ostvarile viši prosjek točnih odgovora od učenika. Razlike u pokazanom znanju postoje i s obzirom na mjesto stanovanja i školski uspjeh. Učenici/e koji ostvaruju odličan uspjeh pokazali su značajno višu razinu znanja od učenika koji ostvaruju vrlo dobar i dobar uspjeh, dok su učenici/e koji ostvaruju dovoljan uspjeh pokazali najni- 
žu razinu znanja. U većini srednjih strukovnih škola znanje o radničkim pravima i poznavanje pravnih propisa kojima se ta prava uređuju, ne poučava se u obliku nastave nekog predmeta ${ }^{6}$ niti u okviru nekoga drugog oblika obrazovanja o pravu mladih, zato ne iznenađuje podatak prema kojem se ispitani učenici najčešće informiraju o pravnim propisima iz radnog prava putem medija $(31,1 \%)$, u krugu obitelji $(19,4 \%)$, u školama (18,5\%). Nešto više od $15 \%$ učenika uopće se ne informira o radnim pravima, nego će o tome misliti kad se zaposle, dok njih 3,6\% radna prava uopće ne zanimaju. Treba naglasiti da masovni mediji mogu ispunjavati važnu informativnu i edukativnu funkciju prenošenjem informacija i znanja o različitim pravima, obvezama, zakonima i politikama i na taj način ostvarivati "instruktivni i konstruktivni utjecaj na razvoj pravnog rasuđivanja" (Tapp i Levine, 1974: 69), ali ne bi trebali biti primarni agens pravne socijalizacije. Za učenike bi to trebale biti škole kao temeljne odgojno-obrazovne institucije koje im trebaju omogućiti i obrazovanje o pravu/ima, stjecanje nekih pravnih znanja i pravno opismenjavanje kao sastavni dio građanskih kompetencija. Ipak, postojeći obrazovni kurikuli samo su sekundarno usmjereni na razvoj građanskih kompetencija, a primarna im je uloga tehničko-instrumentalna, odnosno usmjereni su na prijenos znanja potrebnog za obavljanje poslova na tržištu.

Zbog ograničenja realiziranoga prigodnog uzorka u pogledu neravnomjerne zastupljenosti trogodišnjih strukovnih programa u odnosu na ukupnu populaciju, analiza znanja po odabranim dimenzijama radnih prava prema tipu programa škole nije napravljena, nego je varijabla programa strukovne škole uključena u regresijski model kako bi se utvrdio utjecaj svih obilježja ispitanika na indeks ukupnog znanja o radnim pravima. Ipak, u svrhu daljnje interpretacije i naglašavanja važnosti obrazovanja, ukazujemo na zaključke istraživanja političke socijalizacije mladih u Hrvatskoj. U tim se istraživanjima obrazovni sustav potvrdio kao važan čimbenik političke socijalizacije mladih te je istaknuta važnost obrazovanja za razvijanje društvenih i građanskih kompetencija, odnosno znanja, sposobnosti i vještina za sudjelovanje u društvenom i političkom životu i na tržištu rada (Bagić, 2011; Bagić i Gvozdanović, 2015; Bagić i Šalaj, 2016). To nas upućuje na zaključak da bi se u pogledu pravnog opismenjavanja ponajprije trebalo intervenirati u razvijanje i stjecanje znanja o radničkim pravima u kurikulu trogodišnjih programa, među učenicima koji prvi izlaze na tržište rada. Osobito zato što učenici koji pohađaju trogodišnje strukovne programe imaju niži ekonomski i kulturni kapital u odnosu na učenike četverogodišnjih programa, a školski sustav putem svojih procesa dodatno pridonosi klasnoj stratifikaciji i reprodukciji daljnjih društvenih nejednakosti

6 Primjer dobre prakse nalazimo u razrađenoj nastavnoj jedinici na temu "Što su radnička prava i kako ih ostvariti" u okviru građanskog odgoja i obrazovanja za 3. i 4. razred četverogodišnjih i 2. i 3. trogodišnjih škola (CMS i GOOD, 2019). 
(Doolan, Lukić i Buković, 2016). Ranije spomenuto istraživanje političke pismenosti mladih u Hrvatskoj pokazalo je da socijalno podrijetlo učenika utječe i na razinu političke pismenosti, ali da se to u obrazovnom procesu uspostavljanjem jedinstvenog programa političke edukacije može i treba anulirati (Bagić i Šalaj, 2016: 6465). Drugim riječima, kako u pogledu političke, tako i u pogledu pravne pismenosti, obrazovni sustav ne smije proizvoditi razlike u kompetencijama budućih građana, nego treba obavljati "funkciju anuliranja razlika s kojima učenici ulaze u njega" (Bagić i Šalaj, 2016: 70).

Korištenjem regresijske analize utvrđena je povezanost sociodemografskih $i$ obrazovnih obilježja ispitanika $s$ indeksom ukupnog znanja o izabranim radnim pravima. Također, potvrđen je utjecaj obrazovnog statusa majke na razinu pravne pismenosti ispitanika dok se stupanj obrazovanja očeva i školski uspjeh ispitanika nisu pokazali značajnim za razinu znanja. lako ne možemo model koristiti za neka individualna predviđanja možemo ukazati da su razlike u razini znanja povezane $s$ nekim obilježjima ispitanika, među kojima spol ima najveći utjecaj na razinu znanja.

Zaključak ovog istraživanja o relativno niskoj razini poznavanja izabranih radnih prava među ispitanim maturantima ne odstupa od nalaza istraživanja koja su navedena u teorijskom dijelu rada, a koja su pokazala nisku razinu poznavanja prava među djecom i mladima u Velikoj Britaniji (Ruck i dr., 1998; Youth Access, 2002; Denvir i dr., 2012). Na tragu tih i drugih istraživanja provedenih na ukupnoj populaciji, u Velikoj Britaniji je od 2002. godine u školsku nastavu za učenike u dobi od 11 do 16 godine, uz ostale teme građanskog obrazovanja, uključeno i informiranje o zakonima, zapošljavanju, radnim pravima i obvezama (PLEAS Task Force, 2017:18).

Uz ranije navedena ograničenja, rezultati i zaključci ovog istraživanja mogu se koristiti u kontekstu reforme strukovnog obrazovanja i osposobljavanja i pri izradi programa nastavnih jedinica u okviru građanskog odgoja i obrazovanja, posebno u pogledu ljudsko-pravne i ekonomske dimenzije građanstva. Naime, u različitim konceptima građanskog odgoja i obrazovanja u RH i drugim europskim državama, mogu se izdvojiti sljedeće dimenzije građanstva: ljudsko (pravna), politička, društvena, (inter)kulturna ili međukulturna, socijalna, komunikacijska, gospodarska, i ekološka (Šalaj, 2015: 253). Uključivanjem nekih propisa radnog prava u nastavni okvir građanskog odgoja i obrazovanja, učenicima bi se omogućilo razvijanje pravne pismenosti i stjecanje pravnih znanja koja bi im olakšala ulazak i bolje razumijevanje položaja radnika na tržištu rada. Pritom naglasak nije na nužnosti detaljnog izučavanja radnog zakonodavstva i pravnih propisa. Učenje o radničkim pravima i informiranje učenika o nekim pravnim propisima poput razlikovanja ugovora o radu na neodređeno ili određeno vrijeme, punom tjednom radnom vremenu, trajanju tjednog/godišnjega prekovremenog rada, zaštiti prava i dostojanstva radnika, ko- 
lektivnim ugovorima itd., nužni su za širenje pravnog znanja i pravne pismenosti kao sastavnog dijela građanskih kompetencija. Osim toga, poznavanje određenih pravnih propisa nužno je i za ostvarivanje različitih drugih ciljeva pravne socijalizacije o radnim pravima poput osposobljavanja mladih kao budućih radnika za prepoznavanje potencijalnih pravnih problema na koje mogu naići tijekom rada, procjenu težine tih problema, upoznavanje s postojećim pravnim mehanizmima zaštite radnika, pravodobno traženje pravne pomoći i rješavanje tih problema itd. To nadilazi temu ovog istraživanja, ali s obzirom na nedovoljnu istraženost veza između pravnog "znanja, djelovanja i ishoda" (Denvir i dr., 2012: 596), može biti predmetom nekog budućeg istraživanja. Također, podatci ovog istraživanja, iako dobiveni na prigodnom uzorku, mogu imati određenu aplikativnu vrijednost za razvoj i planiranje sindikalnog djelovanja u Hrvatskoj, napose u pogledu regrutacije novog članstva, što je jedan od ključnih izazova za kolektivno pregovaranje u Hrvatskoj (Bagić, 2019: 107).

Empirijski nalazi prikupljeni ovim istraživanjem trebaju se interpretirati i s obzirom na glavno ograničenje realiziranoga prigodnog uzorka, a to je nemogućnost generalizacije rezultata na cijelu populaciju maturanata srednjih strukovnih škola u Hrvatskoj. Prigodni uzorak koji je za potrebe ovog istraživanja konstruiran i realiziran, određen je zastupljenošću i djelovanjem Sindikata Preporod u srednjim strukovnim školama te omogućava zaključivanje o znanjima učenika/ica koji su sudjelovali $u$ istraživanju. lako je riječ o prigodnom uzorku, s obzirom na veličinu i disperziranost uzorka, odnosno činjenicu da je u istraživanju sudjelovalo 1102 maturanata iz ukupno 54 srednje strukovne škole iz svih regija Hrvatske, autorice smatraju da istraživački nalazi mogu predstavljati relevantan "orijentacijski" okvir za buduća istraživanja te za opisivanje i zaključivanje o istraživanoj temi i za širu populaciju učenika, od one uključene u samo istraživanje. $U$ tom smislu, s obzirom da ranije u Hrvatskoj među učenicima nije testirano poznavanje pravnih propisa kojima se uređuje položaj radnika, autorice smatraju da, neovisno o ograničenjima prigodnog uzorka, istraživački nalazi mogu pridonijeti dosadašnjim znanstvenim spoznajama o pravnom znanju, pravnoj pismenosti i građanskim kompetencijama mladih u srednjim strukovnim školama.

\section{FINANCIJSKA POTPORA}

Projekt "Znanjem do prava" financiran je sredstvima iz Europskoga socijalnog fonda (UP.04.2.1.03.0013). 


\section{LITERATURA}

Bagić D (2019). Croatia: Stability Amidst Heterogeneous Collective Bargaining Patterns. U: Müller T, Vandaele K i Waddington J (ur.). Collective Bargaining in Europe: Towards an Endgame. Volume I. Brussels: The European Trade Union Institute, 93-108.

Bagić D (ur.). (2011). Odgaja li škola dobre građane? Studija o političkoj socijalizaciji hrvatskih srednjoškolaca. Zagreb: GONG i Fakultet političkih znanosti.

Bagić D i Gvozdanović A (2015). Izvještaj: Istraživanje političke pismenosti učenika završnih razreda srednjih škola u Hrvatskoj. Zagreb: GOOD Incijativa, GONG i Institut za društvena istraživanja.

Bagić D i Šalaj B (2016). Kako mladi stječu političko znanje? Analiza čimbenika političke pismenosti hrvatskih maturanata. U: Horvat M i Kovačić M (ur.). Od podanika do građana: razvoj građanske kompetencije mladih. Zagreb: IDIZ i GONG, 51-72.

Baranović B (ur.). (2015). Koji srednjoškolci namjeravaju studirati?: pristup visokom obrazovanju i odabir studija. Zagreb: Institut za društvena istraživanja u Zagrebu.

Bauman Z (2000). Liquid Modernity. Cambridge, UK: Polity Press; Malden, MA: Blackwell.

Beck U (2000). The Brave New World of Work. Cambridge: Polity Press.

Bell D (1973). The Coming of Post-Industrial Society: A Venture in Social Forecasting. New York: Basic Books.

Bourdieu P (1999). Signalna svetla. Prilozi za otpor neoliberalnoj invaziji. Beograd: Zavod za udžbenike i nastavna sredstva.

Buck A, Pleasence P i Balmer NJ (2008). Do Citizens Know How to Deal with Legal Issues? Some Empirical Insights, Journal of Social Policy, 37 (4): 661-681. https://doi. org/10.1017/S0047279408002262

Butković H, Samardžija V, Skazlić I i Čavar I (2018). Nestandardni rad u Hrvatskoj: izazovi i perspektive u odabranim sektorima. Zagreb: Institut za razvoj i međunarodne odnose (IRMO).

Casebourne J, Regan J, Neathey F i Tuphy S (2006). Employment Rights at Work - Survey of Employees 2005, Employment Relations Research Series, No. 51. London: Department of Trade and Industry.

Castells M (2000). Uspon umreženog društva. Zagreb: Golden marketing.

CMS i GOOD (2019). Ekonomska dimenzija građanskog odgoja i obrazovanja: Što su radnička prava i kako ih ostvariti. http://goo.hr/wp-content/uploads/2019/05/GOO-Štosu-radnička-prava.pdf (03. lipnja 2020.)

Cohn ES i White SO (1990). Legal Socialization: A Study of Norms and Rules. New York: Springer-Verlag. https://doi.org/10.1007/978-1-4612-3378-7

Cohn ES i White SO (1997). Legal Socialization Effects on Democratization, International Social Science Journal, 49: 151-171. https://doi.org/10.1111/j.1468-2451.1997.tb00014x

Denvir C, Balmer NJ i Buck A (2012). Informed Citizens? Knowledge of Rights and the Resolution of Civil Justice Problems, Journal of Social Policy, 41 (3): 591-614. https:// doi.org/10.1017/S0047279412000244

Denvir C, Balmer NJ i Pleasence P (2013). When Legal Rights are not a Reality: Do Individuals Know Their Rights and How Can We Tell?, Journal of Social Welfare and Family Law, 35 (1): 139-160. https://doi.org/10.1080/09649069.2013.774764 
Doolan K, Lukić N i Buković N (2016). The Embodiment of Class in the Croatian VET School System, European Journal of Education, 51 (3): 345-359. https://doi.org/10.1111/ ejed.12183

Eurostat (2019). Youth Employment by Sex, Age and Educational Attainment Level. https:// appsso.eurostat.ec.europa.eu/nui/show.do?dataset=yth_empl_010\&lang=en (01. rujna 2020.)

Eurostat (2020). Young People Neither in Employment nor in Education and Training by Sex, Age and Labour Status (NEET rates). http://appsso.eurostat.ec.europa.eu/nui/ show.do?dataset=yth_empl_150\&lang=eng (11. siječnja 2021.)

Finckenauer JO (1998). Legal Socialization: Concepts and Practices, Trends in Organized Crime, 4 (2): 30-40. https://doi.org/10.1007/BF02900336

Friedman LM (1969). Legal Culture and Social Development, Law and Society Review, 4 (1): 29-44. https://doi.org/10.2307/3052760

GONG (2018). Građansko obrazovanje u Hrvatskoj policy preporuke. https://www.gong.hr/ media/uploads/2018pbgoogong.pdf (08. srpnja 2019.)

Gvozdanović A, Ilišin V, Adamović M, Potočnik D, Baketa N i Kovačić M (2019). Istraživanje mladih u Hrvatskoj 2018./2019. Zagreb: Friedrich Ebert Stiftung.

Ilišin V (1999). Mladi na margini društva i politike. Zagreb: Alineja.

Ilišin V i Radin F (ur.). (2002). Mladi uoči trećeg milenija. Zagreb: Institut za društvena istraživanja u Zagrebu i Državni zavod za zaštitu obitelji, materinstva i mladeži u Zagrebu.

Ilišin V, Mendeš I i Potočnik D (2003). Politike prema mladima u obrazovanju i zapošljavanju, Politička misao, 40 (3): 58-89.

Ilišin V (ur.). (2006). Mladi između želja i mogućnosti: položaj, problemi i potrebe mladih Zagrebačke županije. Zagreb: Institut za društvena istraživanja u Zagrebu.

Ilišin V (2007). Youth, Croatia and Europe: an Introduction to the Research. U: Ilišin V (ur.). Croatian Youth and European Integration. Zagreb: Institut za društvena istraživanja u Zagrebu, 11-35.

Ilišin Vi Radin F (ur.). (2007). Mladi:problemiliresurs. Zagreb: Institutza društvena istraživanja. Ilišin V, Bouillet D, Gvozdanović A i Potočnik D (2013). Mladi u vremenu krize. Zagreb: Institut za društvena istraživanja u Zagrebu i Zaklada Friedrich Ebert.

Ilišin V i Spajić Vrkaš V (ur.). (2017). Generacija osujećenih: mladi u Hrvatskoj na početku 21. stoljeća. Zagreb: Institut za društvena istraživanja u Zagrebu.

Kovačić M i Horvat M (2016). Razvoj političkih i građanskih kompetencija mladih - pregled uvođenja građanskog odgoja i obrazovanja u hrvatski obrazovni sustav. U: Horvat M i Kovačić M (ur.). Od podanika do građana: razvoj građanske kompetencije mladih. Zagreb: IDIZ i GONG, 15-29.

Kregar J, Sekulić D, Ravlić S, Zrinščak S, Grubišić K i Petričušić A (2014). Uvod u sociologiju. Zagreb: Pravni fakultet $u$ Zagrebu.

Matković T, Lukić N, Buković N i Doolan K (2013). Destination uncertain? Trends, Perspectives and Challenges in Strengthening Vocational Education for Social Inclusion and Social Cohesion. Luxemburg: European Training Foundation.

Markočić Dekanić A, Gregurović M, Batur M i Fulgosi S (2019). PISA 2018: Rezultati, odrednice i implikacije. Međunarodno istraživanje znanja $i$ vještina učenika. Zagreb: NCVVO. https://mk0pisancvvocpocw453.kinstacdn.com/wp-content/uploads/2019/12/ PISA-2018_izvještaj.pdf (20. rujna 2020.) 
Meager N, Tyers C, Perryman S, Rick J i Willison R (2002). Awareness, Knowledge and Exercise of Individual Employment Rights. London: Department of Trade and Industry.

MZO - Ministarstvo znanosti i obrazovanja RH (2021). ŠeR - Školski e-Rudnik. https://mzo. gov.hr/ser-skolski-e-rudnik-3419/3419 (08. ožujka 2021.)

PLEAS Task Force (2007). Developing Capable Citizens: The Role of Public Legal Education. London: Public Legal Education Task Force.

Pučki pravobranitelj RH (2020). Izvješće pučke pravobraniteljice za 2019. godinu. https:// www.ombudsman.hr/wp-content/uploads/2020/04/Izvješće-pučke-pravobraniteljiceza-2019._3.pdf (20. ožujka 2020.)

Ruck M, Keating DP, Abramovitch R i Koegl CJ (1998). Adolescents' and Children's Knowledge About Rights: Some Evidence for How Young People View Rights in Their Own Lives', Journal of Adolescence, 21 (3): 275-289. https://doi.org/10.1006/ jado.1998.0153

Šalaj B (2015). Novi program građanskog odgoja i obrazovanja u hrvatskim školama: početak ozbiljnog rada na razvoju demokratske političke kulture mladih ili smokvin list ministarstva?. U: Ilišin V, Gvozdanović A i Potočnik D (ur.). Demokratski potencijali mladih u Hrvatskoj. Zagreb: Institut za društvena istraživanja; Centar za demokraciju i pravo Miko Tripalo, 241-268.

Tapp JL i Kohlberg L (1971). Developing Senses of Law and Legal Justice, Journal of Social Issues, 27 (2): 65-91. https://doi.org/10.1111/j.1540-4560.1971.tb00654.x

Tapp JL i Levine FJ (1974). Legal Socialization: Strategies for an Ethical Legality, Stanford Law Review, 27 (1): 1-72. https://doi.org/10.2307/1227929

Touraine A (1971). The Post-Industrial Society: Tomorrow's Social History: Classes, Conflicts and Culture in the Programmed Society. New York: Random House.

Vrban D (2006). Sociologija prava: uvod i izvorišne osnove. Zagreb: Golden marketing Tehnička knjiga.

Waddington J, Müller T i Vandaele H (2019). Setting the Scene: Collective Bargaining Under Neoliberalism. U: Müller T, Vandaele K i Waddington J. (ur.). Collective Bargaining in Europe: Towards an Endgame. Volume I. Brussels: The European Trade Union Institute, 1-32.

Youth Access (2002). Rights to Access: Meeting Young People's Need for Advice., London: Youth Access.

Zakon o radu (2020). Narodne novine, 93/14, 127/17, 98/19 (pročišćeni tekst zakona). https://www.zakon.hr/z/307/Zakon-o-radu (15. veljače 2021.)

Zakon o rodiljnim i roditeljskim potporama (2020). Narodne novine, 85/08, 110/08, 34/11, 54/13, 152/14 i 59/17, 37/20 (pročišćeni tekst zakona). https://zakon.hr/z/214/Zakon-orodiljnim-i-roditeljskim-potporama (15. veljače 2021.)

Zakon o tržištu rada (2020). Narodne novine, 118/18, 32/20 (pročišćeni tekst zakona). https://zakon.hr/z/1751/Zakon-o-tržištu-rada (15. veljače 2021.) 


\title{
Knowledge of Selected Labour Rights Among Vocational School Graduates in Croatia
}

\author{
Ranka JEKNIĆ (ID) https://orcid.org/0000-0001-8503-3634 \\ University of Split, Faculty of Law, Croatia \\ ranka.jeknic@pravst.hr \\ Blanka ČOP (D) https://orcid.org/0000-0002-2519-0993 \\ University of Split, Faculty of Law, Croatia \\ blanka.cop@pravst.hr
}

\section{ABSTRACT}

This paper analyses the results of a survey about the knowledge of selected labour rights among vocational school graduates in Croatia. The survey was conducted during 2019 as a part of the EU project "With Knowledge to Law" involving 1102 graduates from 54 vocational schools in Croatia, from various three-year, four-year and five-year programmes. Using descriptive statistics and regression analysis, the paper aims to determine potential differences in the demonstrated knowledge of selected labour rights among the respondents and whether the sociodemographic and educational characteristics of the respondents impact the level of their legal literacy. The results indicate a low level of knowledge and legal literacy relating to selected labour rights among respondents, as well as a contribution of their sociodemographic and educational characteristics to the index of overall knowledge about selected labour rights. The regression analysis shows that the gender variable has the most influence on the level of legal literacy among surveyed graduates. In addition to reviewing the current situation in terms of the knowledge of surveyed graduates on selected labour rights and encouraging academic and public debates, the findings of this research may have application value in the development of curricula for civic education at different educational levels. They may also support the development and planning of trade union activities in Croatia, especially regarding the recruitment of new members. The research findings potentially contribute to the insufficiently researched topics of legal knowledge, legal literacy, legal culture and legal socialization through which this knowledge is acquired.

Key words: labour rights, legal socialization, legal literacy, vocational schools, civic education 